\title{
Reduction of leptin levels by four cardiac hormones: Implications for hypertension in obesity
}

\author{
MEGHAN L. LANE and DAVID L. VESELY \\ Departments of Medicine, Molecular Pharmacology and Physiology, and James A. Haley VA Medical Center, \\ University of South Florida Morsani School of Medicine, Tampa, FL 33612, USA
}

Received May 24, 2013; Accepted June 7, 2013

DOI: $10.3892 /$ etm.2013.1173

\begin{abstract}
Circulating levels of leptin are increased in obesity and have been proposed to contribute to the development of hypertension in obese individuals. Four cardiac hormones, specifically, vessel dilator, long-acting natriuretic peptide (LANP), kaliuretic peptide and atrial natriuretic peptide (ANP), have blood pressure-lowering properties and correlate with the presence of hypertension in obesity. The objective of this study was to determine whether one or more of these cardiac hormones was able to decrease the levels of leptin in the hypothalamus, an area of the brain that has been demonstrated to synthesize more than $40 \%$ of leptin in the circulation. The effects of these four cardiac hormones on leptin were examined using dose-response curves in the rat hypothalamus, which synthesizes leptin. Vessel dilator, LANP, kaliuretic peptide and ANP maximally decreased the levels of leptin in hypothalamic cells by $79,76,80$ and $62 \%$, respectively $(\mathrm{P}<0.0001$ for each). The cardiac hormones decreased leptin levels over a concentration range of $100 \mathrm{pM}$ to $10 \mu \mathrm{M}$, with the most significant reductions in leptin levels occurring when the concentrations of the hormones were at micromolar levels. The results of the study suggest that the four cardiac hormones lead to significant reductions in hypothalamic leptin levels, which may be an important mechanism for alleviating leptin-induced hypertension in obesity.
\end{abstract}

\section{Introduction}

Leptin is a $16 \mathrm{kDa}$-peptide (167 amino acids) that is synthesized and secreted predominantly by white adipose tissue (1). One of the major effects of this hormone is the control of energy balance via the hypothalamus, which was previously consid-

Correspondence to: Dr David L. Vesely, Departments of Internal Medicine, Molecular Pharmacology and Physiology, University of South Florida Morsani School of Medicine, 13000 Bruce B. Downs Boulevard, Tampa, FL 33612, USA

E-mail: david.vesely@va.gov

Key words: leptin, hypothalamus, hypertension in obesity, cardiac hormones ered to be mediated through binding to leptin receptors in the hypothalamus (2-4). However, leptin levels are higher in the blood leaving the brain than in that entering it, suggesting that leptin may be synthesized in the hypothalamus and other brain tissues (5). More than $40 \%$ of circulating leptin originates from the brain in healthy males (6). Furthermore, the plasma leptin concentrations contributed by the brain demonstrate a six-fold increase in obese males compared with healthy males $(935 \pm 32 \mathrm{ng} / \mathrm{ml}$ in obese versus $160 \pm 59 \mathrm{ng} / \mathrm{ml}$ in healthy males) (6). Leptin is synthesized in the hypothalamus (7). Leptin mRNA expression has been detected in the hypothalamus and this expression of leptin has been demonstrated to be suppressed by $48 \mathrm{~h}$ of fasting (7). In the hypothalamus, the leptin gene is, thus, regulated by nutrient availability. The detection of leptin expression in the hypothalamus by reverse transcription-polymerase chain reaction (RT-PCR) has been confirmed with sequence analysis using rat hypothalami (7). Leptin protein has also been demonstrated to be present in rat hypothalami by immunocytochemistry (7). Therefore, leptin gene expression and leptin itself are present in the hypothalamus.

Although leptin has been suggested to reduce appetite, obese individuals generally exhibit high circulating leptin levels (8) and, as mentioned previously, a large proportion of the high leptin levels that are apparent in obesity originate in the brain, with six-fold more leptin secreted from the brain into the circulation of obese versus healthy individuals (6). It has been suggested that these high circulating levels of leptin in obesity function pathophysiologically for the development of hypertension (8). Epidemiological studies have indicated that $65-75 \%$ of the risk for hypertension is excess weight $(9,10)$. Chronic increases in leptin levels result in a persistent elevation in mean arterial pressure and this hypertensive blood pressure is rapidly reversed with cessation of leptin administration (11). Acute infusions of leptin have also been demonstrated to lead to an abrupt increase in blood pressure (12). Similar increases in systolic blood pressure have been observed in transgenic mice overexpressing leptin (13).

The heart and adipose tissue are endocrine organs and studies have increasingly suggested that cross-talk exists between them, although the precise mechanism is poorly defined (14-19). The heart synthesizes four hormones, the products of a single gene, which have significant blood pressure-lowering effects (20). These cardiac hormones, which are vessel dilator, long-acting natriuretic peptide (LANP), 
atrial natriuretic peptide (ANP) and kaliuretic peptide, are vasodilators, with blood pressure-lowering properties in animals (21-26) and humans (27-29). The original hypothesis for hypertension was the presence of a defect in the production of the blood pressure-lowering ANPs $(30,31)$. However, experimental data have revealed that, rather than being decreased, the levels of these blood pressure-lowering peptides are elevated in the circulation in an apparent attempt to overcome the elevated blood pressure (30-34). ANP levels are increased in essential hypertension $(30,34)$. The hypertension in obesity is also associated with increased circulating concentrations of ANP (32), LANP (33) and vessel dilator (33), which decrease into the normal range when the high blood pressure is reduced by weight loss (32-34). In the present study, we hypothesized that since the levels of cardiac hormones correlate with blood pressure in obesity (32-34), the blood pressure-reducing effects of these hormones (20-29) may be mediated, in part, by decreased leptin production in the hypothalamus.

\section{Materials and methods}

Cardiac hormones. The cardiac hormones (vessel dilator, ANP, kaliuretic peptide and LANP) were obtained from Phoenix Pharmaceuticals, Inc., Belmont, CA, USA.

Hypothalamic cells. Hypothalamic cells (ATCC no. CRL-2005; DI TNC1) were obtained from the American Type Culture Collection (ATCC) Manassas, VA, USA. The ATCC authenticated this cell line.

Culture of hypothalamic cells. Propagation of the hypothalamic cells was performed in Dulbecco's Modified Eagle's medium with an addition of $10 \%$ heat-inactivated fetal bovine serum (Sigma Chemical Corporation, St. Louis, MO, USA) and $1 \%$ penicillin, streptomycin and fungizone at a temperature of $37^{\circ} \mathrm{C}$, as recommended by the ATCC. The number of cells in culture was $1.44 \times 10^{6}$ cells $/ \mathrm{ml}$. Cells were dispensed into new flasks with subculturing every 6 days. The growth medium was changed every 3 days.

Leptin enzyme-linked immunosorbent assay (ELISA). The Quantikine ${ }^{\circledR}$ leptin immunoassay ELISA used to measure leptin levels was obtained from R\&D Systems (Minneapolis, MN, USA). This $3.5 \mathrm{~h}$ solid phase ELISA contained E. coli-expressed recombinant leptin and antibodies raised against the recombinant leptin. This quantitative sandwich enzyme immunoassay utilized a monoclonal antibody specific for leptin. The immunoassay has been shown to quantitate recombinant leptin accurately. Results obtained by measuring natural leptin revealed that the dose-response curves obtained with the recombinant Quantikine ${ }^{\circledR}$ assay paralleled the curves with natural leptin. The assay had a $98 \%$ recovery of leptin in the previously mentioned cell culture media. The minimal detectable concentration of leptin in this assay was $7.8 \mathrm{pg} / \mathrm{ml}$. The levels of leptin measured are the amount in the cells plus the amount of leptin secreted into the media.

Leptin protocol. The hypothalamic cells $\left(1.44 \times 10^{6}\right.$ cells $\left./ \mathrm{ml}\right)$ were subcultured for $24 \mathrm{~h}$, prior to $50 \mu \mathrm{l}$ cell culture supernatant being added to 96-well plates with $50 \mu 1$ media, containing
$100 \mathrm{pM}, 1 \mathrm{nM}, 10 \mathrm{nM}, 100 \mathrm{nM}, 1 \mu \mathrm{M}$ and $10 \mu \mathrm{M}$ of each of the four cardiac hormones, separately ( $\mathrm{n}=9$ for each concentration). The hypothalamic cells were subsequently evaluated using the leptin ELISA from R\&D Systems. Following this, the mean of the nine measurements at each concentration of the respective peptide hormones was then calculated and this was compared with the mean of the leptin concentrations in the control hypothalami, which had not been exposed to any of the cardiac hormones. The leptin data are shown in the figures as the decrease in the leptin level (i.e., the percentage decrease) compared with the level of leptin in the untreated hypothalami. The standards from R\&D Systems were added to the blank wells to serve as reference points for known leptin concentrations. In this assay, absorbance was recorded at a $540 \mathrm{~nm}$ wavelength using a 96-well BioTek Gen 5, Synergy Mx microplate reader (BioTek Instruments, Inc., Winooski, VA, USA). There were 48 hypothalamic controls in these experiments.

Statistical analysis. Data are expressed as the mean \pm standard error of the mean (SEM). Statistical analysis of the data were performed by one way analysis of variance (ANOVA) with a repeated measures design for within-group comparisons, using a statistical module of Excel software (Microsoft Corporation, Redmond, WA, USA). A value of $\mathrm{P}<0.05$ was considered to indicate a statistically significant difference.

\section{Results}

Vessel dilator decreases the hypothalamic concentrations of leptin by up to $79 \%$. Vessel dilator decreased the concentration of leptin by a maximum of $79 \%(\mathrm{P}<0.0001)$ from the control value of $85 \pm 4 \mathrm{pg} / \mathrm{ml}$. The maximal reduction was obtained when the highest concentration of vessel dilator, i.e., $10 \mu \mathrm{M}$ was used (Fig. 1). At the lowest concentration of the vessel dilator $(100 \mathrm{pM})$, there was a $26 \%$ reduction in the concentration of leptin $(\mathrm{P}<0.05)$. The dose-response curves indicated that vessel dilator also decreased leptin levels by $54,58,55$ and $73 \%$ at concentrations of 1,10 and $100 \mathrm{nM}$ and $1 \mu \mathrm{M}$, respectively ( $\mathrm{P}<0.001$ for each; Fig. 1).

LANP decreases hypothalamic leptin by up to 76\%. LANP decreased leptin levels by up to $76 \%(\mathrm{P}<0.0001)$ in the hypothalami, with the maximal reduction occurring at a LANP concentration of $1 \mu \mathrm{M}$ (Fig. 2). LANP, similar to vessel dilator, decreased leptin by the smallest amount at its lowest concentration, $100 \mathrm{pM}$; however, this $37 \%$ reduction in leptin was significant at $\mathrm{P}<0.01$. There was a significant $(\mathrm{P}<0.001)$ reduction in leptin levels at each of the other concentrations of LANP, with reductions of 53, 62, 65 and 59\% at concentrations of 1,10 and $100 \mathrm{nM}$ and $10 \mu \mathrm{M}$ LANP, respectively (Fig. 2).

Reduction of leptin levels in the hypothalami secondary to ANP. ANP, like LANP, caused its maximal reduction $(62 \%$; $\mathrm{P}<0.0001)$ in hypothalamic leptin levels at a concentration of $1 \mu \mathrm{M}$ and its smallest reduction $(28 \% ; \mathrm{P}<0.05)$ at a concentration of $100 \mathrm{pM}$ (Fig. 3). There was a significant reduction in leptin levels at all concentrations of ANP, with reductions of $54,57,56$ and $54 \%$ at concentrations of 1,10 and $100 \mathrm{nM}$ and $10 \mu \mathrm{M}$, respectively ( $\mathrm{P}<0.001$ for each concentration). 

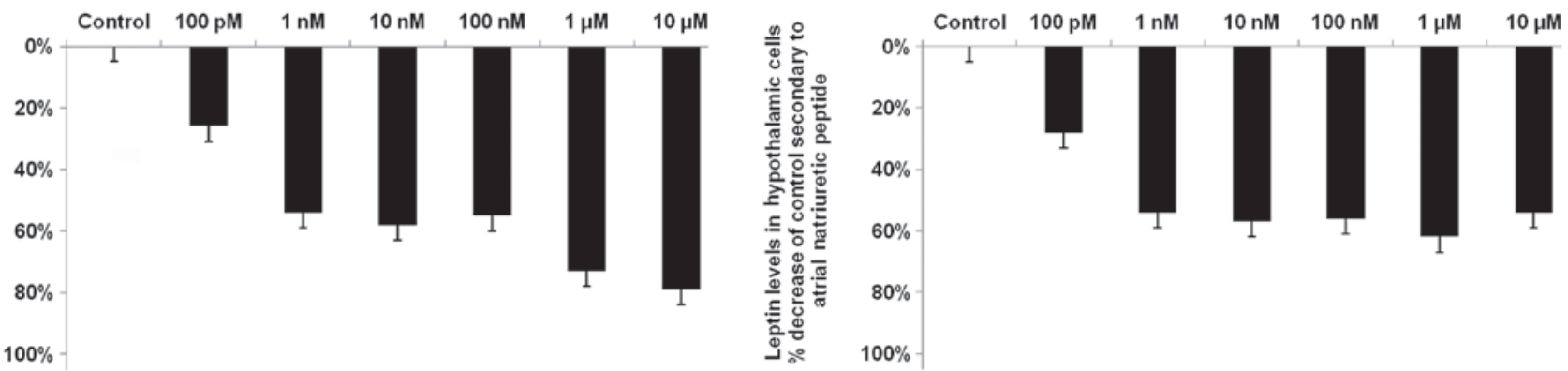

Figure 1. Vessel dilator decreases the hypothalamic concentration of leptin by up to $79 \%$. Vessel dilator maximally decreased leptin levels in the hypothalamic cells by $79 \%(\mathrm{P}<0.0001)$ at a concentration of $10 \mu \mathrm{M}$ in comparison with the control $(85 \pm 4 \mathrm{pg} / \mathrm{ml})$. Vessel dilator caused a significant reduction in leptin levels in the hypothalamus at each of its concentrations, with reductions of $26,54,58,55$ and $73 \%$ at concentrations of $100 \mathrm{pM}, 1 \mathrm{nM}, 10 \mathrm{nM}, 100 \mathrm{nM}$ and $1 \mu \mathrm{M}$, respectively. These results were significant at $\mathrm{P}<0.001$, with the exception of the $100 \mathrm{pM}$ concentration $(\mathrm{P}<0.05)$, as demonstrated by analysis of variance (ANOVA) with a repeated measures design for within-group comparisons. $n=9$ for each concentration of vessel dilator; $n=48$ for controls.

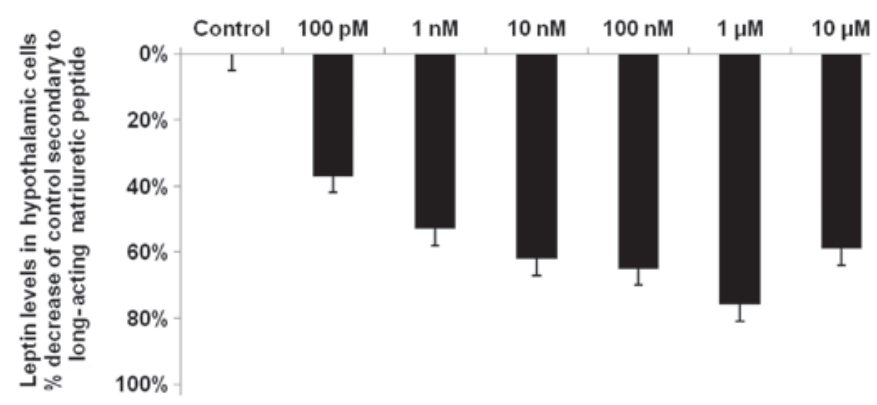

Figure 2. Long-acting natriuretic peptide (LANP) decreases hypothalamic leptin by up to $76 \%$. LANP decreased leptin levels by $76 \%(\mathrm{P}<0.0001)$ at a concentration of $1 \mu \mathrm{M}$. LANP decreased leptin levels by 37, 53, 62, 65 and $59 \%$ at concentrations of $100 \mathrm{pM}, 1 \mathrm{nM}, 10 \mathrm{nM}, 100 \mathrm{nM}$ and $10 \mu \mathrm{M}$, respectively. These results were significant at $\mathrm{P}<0.001$, with the exception of the $100 \mathrm{pM}$ concentration $(\mathrm{P}<0.01)$, as demonstrated by analysis of variance (ANOVA) with a repeated measures design for within-group comparisons. $\mathrm{n}=9$ for each concentration of LANP; $\mathrm{n}=48$ for controls.

Kaliuretic peptide decreases hypothalamic leptin by up to $80 \%$. Kaliuretic peptide decreased leptin levels by up to $80 \%(\mathrm{P}<0.0001)$, with a maximal reduction occurring at the highest concentration of kaliuretic peptide, i.e., $10 \mu \mathrm{M}$ (Fig. 4). Kaliuretic peptide also caused a significant $(\mathrm{P}<0.0001) 72 \%$ reduction in leptin levels at a concentration of $1 \mu \mathrm{M}$. Kaliuretic peptide significantly decreased leptin levels at each of its concentrations in the dose-response curves, with reductions of $35,49,54$ and $64 \%$ at concentrations of $100 \mathrm{pM}$ and 1 , 10 and $100 \mathrm{nM}(\mathrm{P}<0.001$ for each, with the exception of the $100 \mathrm{pM}$ concentration where $\mathrm{P}<0.01$ ). Thus, with respect to the maximal reduction in leptin levels, the effects of vessel dilator, LANP and kaliuretic peptide were approximately equal and each of these cardiac hormones had a stronger ability than ANP to decrease leptin levels.

\section{Discussion}

Vessel dilator, LANP, kaliuretic peptide and ANP each significantly decreased leptin levels in the hypothalamus, an area of
Figure 3. Atrial natriuretic peptide (ANP) decreases the hypothalamic leptin level by up to $62 \%$. ANP decreased leptin levels by $62 \%(\mathrm{P}<0.0001)$ at a concentration of $1 \mu \mathrm{M}$. ANP decreased leptin levels by 28, 54, 57, 56 and $54 \%$ at concentrations of $100 \mathrm{pM}, 1 \mathrm{nM}, 10 \mathrm{nM}, 100 \mathrm{nM}$ and $10 \mu \mathrm{M}$, respectively. These reductions in leptin levels were significant at $\mathrm{P}<0.001$, with the exception of the $100 \mathrm{pM}$ concentration $(\mathrm{P}<0.05)$, as demonstrated by analysis of variance (ANOVA) with a repeated measures design for within-group comparisons. $n=9$ for each concentration of ANP; $n=48$ for controls.

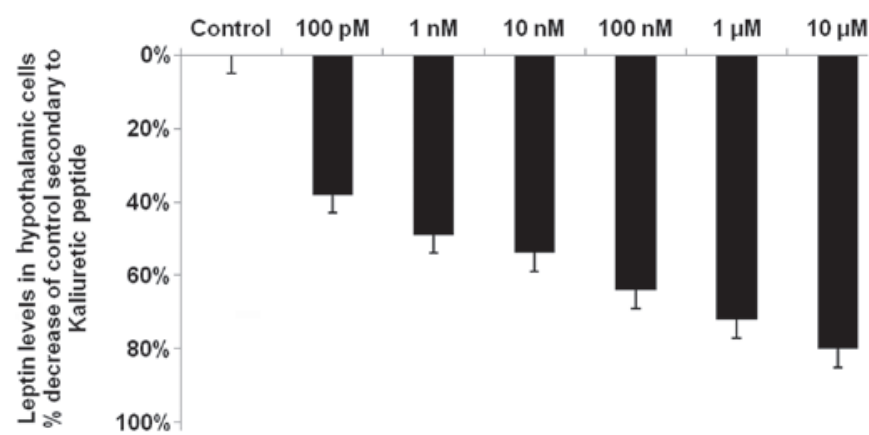

Figure 4. Kaliuretic peptide decreases hypothalamic leptin concentrations by up to $80 \%$. Kaliuretic peptide decreased the leptin level by $80 \%(\mathrm{P}<0.0001)$ at a concentration of $10 \mu \mathrm{M}$. Kaliuretic peptide decreased leptin levels by 35,49 , 54,64 and $72 \%$ at concentrations of $100 \mathrm{pM}, 1 \mathrm{nM}, 10 \mathrm{nM}, 100 \mathrm{nM}$ and $1 \mu \mathrm{M}$, respectively. These results were significant at $\mathrm{P}<0.001$, with the exception of the $100 \mathrm{pM}$ concentration $(\mathrm{P}<0.01)$, as demonstrated by analysis of variance (ANOVA) with a repeated measures design for within-group comparisons. $\mathrm{n}=9$ for each concentration of kaliuretic peptide; $\mathrm{n}=48$ for controls.

the brain that synthesizes leptin (7). The brain contributes more than $40 \%$ of the leptin in the circulation (6). The hypothalamus and brain contribute approximately six-fold more to the circulating concentration of leptin in obese individuals in comparison with the concentration in the circulation of healthy individuals (6), which may be the reason that leptin is elevated in the circulation of obese individuals (8). This suggests that there is an increase of leptin being synthesized in the hypothalamus in obese individuals. Furthermore, this indicates that the hypothalamus is significant in the elevation of leptin levels in the circulation of obese individuals with hypertension (6). With regard to hypertension in obesity, the present results indicated that the hypertension may be treated with the vasodilatory cardiac hormones investigated in the present study, since increased levels of leptin are correlated with the development of hypertension in obese individuals $(8,11,12)$. The ability of all four cardiac hormones to markedly decrease leptin levels was suggestive of a novel potential treatment target for hypertension in obesity, since these four cardiac hormones have demonstrated blood pressure-lowering properties (21-29). The circulating concentrations of these four cardiac hormones 
increase in individuals with high blood pressure in an apparent attempt to overcome the constriction of the blood vessels (34). In calorie-restricted weight reduction, the four cardiac hormones have been demonstrated to be correlated in a linear fashion $(\mathrm{P}<0.0001)$ with blood pressure reduction (34). During this blood pressure reduction, plasma aldosterone and plasma renin were inversely correlated with the concentration of the four cardiac hormones and blood pressure (34). These results were consistent with the ability of ANP to inhibit renin release and aldosterone secretion from the adrenal gland, as well as the strong inhibition of renin release mediated by vessel dilator $(25,34)$. The ability of these hormones to decrease leptin levels thus suggests one mechanism for the known correlation with blood pressure in obesity (32-34).

In the present study, the cardiac hormones were demonstrated to directly decrease leptin levels in the hypothalamus. It may be expected that the cardiac hormones also have the ability to decrease leptin levels in other leptin-synthesizing tissues, as leptin promotes angiogenesis by increasing vascular endothelial growth factor (VEGF) levels (35) and the cardiac hormones have been demonstrated to decrease levels of VEGF and the VEGFR-2 receptor by up to $92 \%$ (36). Thus, one of the mediators (VEGF) by which leptin causes vascular permeability and angiogenesis (35) is inhibited by each of the cardiac hormones (36). This suggests that the effects of leptin on blood vessels may also be decreased by the four cardiac hormones. In addition, ANP has been shown to inhibit leptin release from adipose tissues (37), with receptors for ANP being present in adipose tissues (38).

Hormone-sensitive lipase breaks down triglycerides into non-essential fatty acids and glycerol (14). This hydrolysis is commonly termed lipolysis (14). ANP activates hormone-sensitive lipase through an increase in cyclic guanosine 3',5'-monophosphate (cGMP) production, via the enhancement of guanylyl cyclase (15). Furthermore, the three other cardiac hormones synthesized by the ANP prohormone gene also markedly enhance cGMP production by stimulating guanylyl cyclase (39). The application of ANP via a microdialysis probe has been shown to increase lipolysis in abdominal subcutaneous adipose tissue of healthy young males $(14,16)$, while a systemic ANP infusion increases lipolysis $(17,18)$, even at physiological concentrations (19). Prior to the demonstration that cardiac hormones were able to cause lipid mobilization, catecholamines and insulin were considered the major acute regulators of lipid mobilization and they act via a cyclic adenosine 5'-phosphate (AMP)-dependent regulation of lipolysis (14). By contrast, the cardiac hormones activate the guanylyl cyclase-cGMP pathway $(15,20,39)$, which is completely independent from the cyclic AMP-dependent pathway in adipose cells (15). Resistance to catecholamine-induced lipolysis in subcutaneous adipose tissue has been demonstrated in obese adults (40) and obese children (41). Since the cardiac hormones increase lipolysis in obese subjects, as well as helping to alleviate obesity-interrelated hypertension mediated by leptin, this suggests they may be a multi-targeted novel therapy for obesity.

\section{Acknowledgements}

The authors would like to thank Karen Murphy for excellent secretarial assistance. The contents of this publication do not represent the views of the Department of Veterans Affairs or the United States Government. This work was supported in part by grants from the James and Esther King Florida Biomedical Research Program, the Florida Department of Health, and the Mama Mare Breast Cancer Foundation.

\section{References}

1. Kshatriya S, Lui K, Salah A, Szombathy T, Freeman RH, Reams GP, Spear RM and Villarreal D: Obesity hypertension: the regulatory role of leptin. Int J Hypertens 2011: 270624, 2011.

2. Lönnqvist F: The obese $(o b)$ gene and its product leptin - a new route toward obesity treatment in man? QJ Med 89: 327-332, 1996.

3. Misra A and Garg A: Leptin, its receptor and obesity. J Investig Med 44: 540-548, 1996.

4. Tartaglia LA, Dembski M, Weng X, Deng N, Culpepper J, Devos R, Richards GJ, Campfield LA, Clark FT, Deeds J, et al: Identification and expression cloning of a leptin receptor, OB-R. Cell 83: 1263-1271, 1995.

5. Esler M, Vaz M, Collier G, Nester P, Jennings G, Kaye D, Seals D and Lambert G: Leptin in human plasma is derived in part from the brain, and cleared by the kidneys. Lancet 351: 879-880, 1998.

6. Eikelis N, Lambert G, Wiesner G, Kaye D, Schlaich M, Morris M, Hastings J, Socratous F and Esler M: Extra-adipocyte leptin release in human obesity and its relation to sympathoadrenal function. Am J Physiol Endocrinol Metab 286: E774-E752, 2004.

7. Morash B, Li A, Murphy PR, Wilkinson M and Ur E: Leptin gene expression in the brain and pituitary gland. Endocrinology 140: 5995-5998, 1999

8. Considine RV, Sinha MK, Heiman ML, Kriauciunas A, Stephens TW, Nyce MR, Ohannesian JP, Marco CC, McKee LJ, Bauer TL and Caro JF: Serum immunoreactive-leptin concentrations in normal-weight and obese humans. New Engl J Med 334: 292-295, 1996.

9. Garrison RJ, Kannel WB, Stokes J III and Castelli WP: Incidence and precursors of hypertension in young adults: the Framingham Offspring Study. Prev Med 16: 235-251, 1987.

10. Wofford MR and Hall JE: Pathophysiology and treatment of obesity hypertension. Curr Pharm Des 10: 3621-3637, 2004.

11. Shek EW, Brands MW and Hall JE: Chronic leptin infusion increases arterial pressure. Hypertension 31: 409-414, 1998.

12. Yuan K, Yu J, Shah A, Gao S, Kim SY, Kim SZ, Park BH and Kim SH: Leptin reduces plasma ANP level via nitric oxide-dependent mechanism. Am J Physiol Regul Integr Comp Physiol 298: R1007-R1016, 2010.

13. Huang F, Xiong X, Wang H, You S and Zeng H: Leptin-induced vascular smooth muscle cell proliferation via regulating cell cycle, activating ERK1/2 and NF-kappaB. Acta Biochim Biophys Sin (Shanghai) 42: 325-331, 2010.

14. Sengenès C, Berlan M, De Glisezinski I, Lafontan M and Galitzky J: Natriuretic peptides: a new lipolytic pathway in human adipocytes. FASEB J 14: 1345-1351, 2000.

15. Sengenès C, Bouloumie A, Hauner H, Berlan M, Busse R, Lafontan M and Galitzky J: Involvement of a cGMP-dependent pathway in the natriuretic peptide-mediated hormone-sensitive lipase phosphorylation in human adipocytes. J Biol Chem 278: 48617-48626, 2003.

16. Moro CC, Galitzky J, Sengenès C, Crampes F, Lafontan M and Berlan M: Functional and pharmacological characterization of the natriuretic peptide-dependent lipolytic pathway in human fat cells. J Pharmacol Exp Ther 308: 984-992, 2004.

17. Uehlinger DE, Weidemann P, Gnädinger MP, Hasler L, Bachmann C, Shaw S, Hellmüller B and Lang RE: Increase in circulating insulin induced by atrial natriuretic peptide in normal humans. J Cardiovasc Pharmacol 8: 1122-1129, 1986.

18. Galitzky J, Sengenès C, Thalamus C, Marques MA, Senard JM, Lafontan $\mathrm{M}$ and Berlan M: The lipid-mobilizing effect of atrial natriuretic peptide is unrelated to sympathetic nervous system activation or obesity in young men. J Lipid Res 42: 536-544, 2001.

19. Birkenfeld AL, Boschmann M, Moro C, Adams F, Heusser K, Franke G, Berlan M, Luft FC, Lafontan M and Jordan J: Lipid mobilization with physiological atrial natriuretic peptide concentrations in humans. J Clin Endocrinol Metab 90: 3622-3628, 2005.

20. Vesely DL: Natriuretic hormones. In: Seldin and Giebisch's, The Kidney: Physiology and Pathophysiology. Alpern RJ, Moe OW and Caplan M (eds). 5th edition. Elsevier/North - Holland Biomedical Press, Amsterdam, pp1241-1281, 2013. 
21. Martin DR, Pevahouse JB, Trigg DJ, Vesely DL and Buerket JE: Three peptides from the ANF prohormone $\mathrm{NH}_{2}$-terminus are natriuretic and/or kaliuretic. Am J Physiol 258: F1401-F1408, 1990.

22. Gunning ME, Brady HR, Otuechere G, Brenner BM and Ziedel ML: Atrial natriuretic peptide(31-67) inhibits $\mathrm{Na}^{+}$ transport in rabbit inner medullary collecting duct cells. Role of prostaglandin E2. J Clin Invest 89: 1411-1417, 1992.

23. Benjamin BA and Peterson TV: Effects of proANF-(31-67) on sodium excretion in conscious monkeys. Am J Physiol 269: R1351-R1355, 1995.

24. Zeidel ML: Regulation of collecting duct $\mathrm{Na}^{+}$reabsorption by ANP 31-67. Clin Exp Pharmacol Physiol 22: 121-124, 1995.

25. Villarreal D, Reams GP, Taraben A and Freeman RH: Hemodynamic and renal effects of proANF31-67 in hypertensive rats. Proc Soc Exp Biol Med 221: 166-170, 1999.

26. Dietz JR, Scott DY, Landon CS and Nazian SJ: Evidence supporting a physiological role for proANP-(1-30) in the regulation of renal excretion. Am J Physiol Regul Integr Comp Physiol 280: R1510-R1517, 2001

27. Vesely DL, Douglass MA, Dietz JR, Gower WR Jr, McCormick MT, Rodriguez-Paz G and Schocken DD: Three peptides from the atrial natriuretic factor prohormone amino terminus lower blood pressure and produce diuresis, natriuresis and/or kaliuresis in humans. Circulation 90: 1129-1140, 1994

28. Vesely DL, Douglass MA, Dietz JR, Giordano AT, McCormick MT, Rodriguez-Paz G and Schocken DD: Negative feedback of atrial natriuretic peptides. J Clin Endocrino Metab 78: 1128-1134, 1994

29. Vesely DL, Dietz JR, Parks JR, Baig M, McCormick MT Cintron G and Schocken DD: Vessel dilator enhances sodium and water excretion and has beneficial hemodynamic effects in persons with congestive heart failure. Circulation 98: 323-329, 1998.

30. Sugarawa A, Nakao K, Sakamoto M, Morii N, Yamada T, Itoh H, Shiono $\mathrm{S}$ and Imura H: Plasma concentration of atrial natriuretic polypeptide in essential hypertension. Lancet 2: 1426-1427, 1985.

31. Arendt R, Gerbes A, Ritter D, Stangl E and Zähringer J: Atrial natriuretic factors in plasma of patients with arterial hypertension, heart failure or cirrhosis of the liver. J Hypertens Suppl 4: S131-S135, 1986
32. McMurray RW Jr and Vesely DL: Weight reduction decreases atrial natriuretic factor and blood pressure in obese patients. Metabolism 38: 1231-1237, 1989.

33. McMurray RW Jr and Vesely DL: Weight reduction decreases the circulating concentration of the N-terminus of the ANF prohormone. Am J Med Sci 303: 2-8, 1992.

34. McMurray RW Jr and Vesely DL: Calorie-restricted weight reduction, blood pressure, and atrial natriuretic peptides. Nutrition 9: 178-182, 1993.

35. Cao R, Brakenhielm E, Wahlestedt C, Thyberg J and Cao Y: Leptin induces vascular permeability and synergistically stimulates angiogenesis with FGF-2 and VEGF. Proc Natl Acad Sci USA 98: 6390-6395, 2001.

36. Nguyen JP, Frost CD, Lane ML, Skelton lv WP, Skelton M and Vesely DL: Novel dual inhibitors of vascular endothelial growth factor and VEGFR2 receptor. Eur J Clin Invest 42: 1061-1067, 2012.

37. Fain JN, Kanu A, Bahouth SW, Gowan GS and Lloyd Hiler M: Inhibition of leptin release by atrial natriuretic peptide (ANP) in human adipocytes. Biochem Pharmacol 65: 1883-1888, 2003.

38. Sarzani R, Dessì-Fulgheri P, Paci VM, Espinosa E and Rappelli A: Expression of natriuretic peptide receptors in human adipose and other tissues. J Endocrinol Invest 19: 581-585, 1996.

39. Vesely DL: Peptides from the N-terminus of the atrial natriuretic factor prohormone enhance guanylate cyclase activity and increase cyclic GMP levels in a wide variety of tissues. Mol Cell Biochem 109: 43-50, 1992.

40. Jensen MD, Haymond MW, Rizza RA, Cryer PE and Miles JM: Influence of body fat distribution on free fatty acid metabolism in obesity. J Clin Invest 80: 1168-1173, 1989.

41. Bougnères $\mathrm{P}$, Stunff CL, Pecqueur C, Pinglier E, Adnot P and Ricquier D: In vivo resistance of lipolysis to epinephrine. A new feature of childhood onset obesity. J Clin Invest 99: 2568-2573, 1997. 